unless it can be shown that they are advancing with the dip of soft-bedded strata which flank the harder rocks that form the mountains.

I believe that instances of this kind have occurred in New Zealand, especially on the west side of the mountains.

The great valleys, however, which exist in the Crystalline rocks, and which are 'rock-basins,' have become so by unequal axial motion, which, in the case of Otago, has generally been a subsidence of the mountain-centres, more rapid on the west than the east, and accompanied by a rise of the flanking formation. However, I can have no doubt that in the schistose formations, and other stratified rocks having alternations of hard and soft beds, the valleys have been excavated in the strike of the soft strata by simple erosion.

In the case of the massive Crystalline rocks, I have reason to suppose that the valleys, such as are occupied by the true coastsounds, have originally followed lines of injected basic rocks, that invaded the crystalline mass subsequent to its original metamorplism, and which basic rocks, decomposing more freely than the gueissic group on the subsequent elevation of the land, gave way before the descending ice. It seems to me that the essential condition to the existence of glaciers is a lofty plateau, or slightly inclined mountaintop, on which the snow rests in sufficient quantity to descend into the lower levels as its only means of escape. The greatest erosion takes place where it descends over the edge of this plateau, or 'breeding-ground;' and if there is a soft 'run' in the rocks, it must cut a notch there which will extend into the higher country as a deep valley. I believe I can prove that it has been thus that all our principal valleys have been formed. Ice is only, after all, one of the ordinary destructive forces, the effect of which has, perhaps, been rather underrated; but there has been no new erosive agency added to that formerly known to geologists. The ice-fall acts just like a great cascade in a river, at which point the greatest erosion goes on-that which is effected by the gently running part of the stream being small. The only supposed new point in these discoveries is the excavation, or ploughing action, by the ice of the glacier after it has descended to the valley-level, and with that $I$ certainly do not agree.

Trusting that I can shortly support my views with full details, I remain, my dear Sir Roderick, yours sincerely,

Dunedin: Aprit 18, 1865.

Janes Hector.

\title{
GEOLOGY OF MATLOCK AND THE NEIGHBOURHOOD.
}

To the Editor of the Geological Magazine.

Sir,-Allow me, through the medium of your Magazine, to direct the attention of Geological tourists during the ensuing autumn to some interesting spots in a part of Derbyshire not yet sufficiently known. The Mountain-limestone around Matlock presents very instructive sections, which have lately been extended by quarrying. 
A Geologist may now be able to ascertain whether there is a real fault between the High Tor and Masson Hill, or whether the fault be only apparent through the falling down of the strata on the western side of the great rent to which the Tor originally owed its existence. A part of the second or under bed of toadstone may now be seen near Mr. Stevenson's Paint-works, under the High Tor. Shreds or fragments of raised beaches may be recognized behind Matlock Bath and other parts of the valley; but the finest specimens of raised beaches, of dimensions admitting of being explained by ordinary earthquakes, may be traced to the south of Cromford, on the right hand of the Cromford and Wirksworth Road. The Black Rocks to the left of the road, at a much greater elevation, reveal in a very impressive manner the action of oceanic waves, tides, and currents. The angles of the jointed blocks of hard Millstonegrit, and in many instances the fractured surfaces, appear as if they had resisted atmospheric action or weathering for thousands of years. Furrows, a few inches in depth, have in some places evidently been worn away by rain; but very few signs of the effects (in the shape of powdered grit) of pluvial disintegration can be discovered, while several of the crevices are partly filled, not by decayed grit, but by a sandy calcareous clay of the same nature as that which may be seen covering considerable areas in Matlock Valley. This clay contains fragments more or less rounded, and was probably deposited by the sea during the last submergence of the land. The Black Rocks have acquired their present shape, not by disintegration, but by the displacement of blocks, leaving walls and pillars, with intervening passages, the sides of which are nearly as fresh-looking as when the rocks were jointed. Here the Geologist can likewise see rock-basins on the sides of the cliffs, and in positions to which an undermining agency only could have had access. But such hollows on the sides of rocks are more common on Stanton Moor, a few miles to the northwest of Matlock. There also may be seen pillars of rocks like chimneys, consisting of square blocks, apparently piled up, but really the remaining fragments of jointed strata. Farther north, on the other side of the Derwent, the Millstone-grit rises in pillars, like the Cheese-wring of Cornwall. Here they are called 'Batches of Old Cakes.' That they are very old is evident, for their shape cannot be explained by any weathering process now operating on the spot, but would seem to point to the lateral action of the sea. Somekinds of Millstone-grit are peculiarly adapted to resist weathering. The longer they are exposed to the atmosphere, the harder their surfaces become; and, with their usual mossy covering, I am convinced they may retain certain shapes for a very long period. The Post-office and other houses in Cromford were built seventy years ago, and the marks of mason's tools are now as perfect and fresh-looking as when the stones were hewn.

Behind Matlock High Tor there is a deep rent, the bottom and ramifications of which have been partly filled with a kind of sand, quantities of which have been brought to the surface during leadmining operations. An examination of the sediment in this rent, or 
roofless cave (excepting where it is covered by a sea-worn arch); might lead to a better understanding of the origin of deposits in caves. Here no fresh water could ever have percolated to any extent, as the High Tor is surrounded by low ground.

On the footpath between Cromford and Bonsall, I have seen smoothed surfaces and markings on the limestone rock, which, if they are not glacial, are probably as much so as many phenomena which are attributed to icebergs, if not to sub-aërial glaciers. I believe the rock is called the Bloody Stone. D. Mackintosh.

\section{PERMIAN STRATA IN THE VALE OF CLWYD.}

\section{To the Editor of the Geological Magazine.}

Sin,-I have recently observed on the eastern side of the head of the Vale of Clwyd, a small exposure of Permian strata, intervening between the Bunter Sandstone and the Mountain-limestone. The Permian is not marked on the map of the Geological Survey as existing anywhere in the Vale of Clwyd; and as its occurrence gives evidence of even still greater antiquity to an important erosion of the Mountain-limestone of North Wales than that mentioned by Professor Jukes in your last number, I send the accompanying sketchsection for publication in the Magazine.

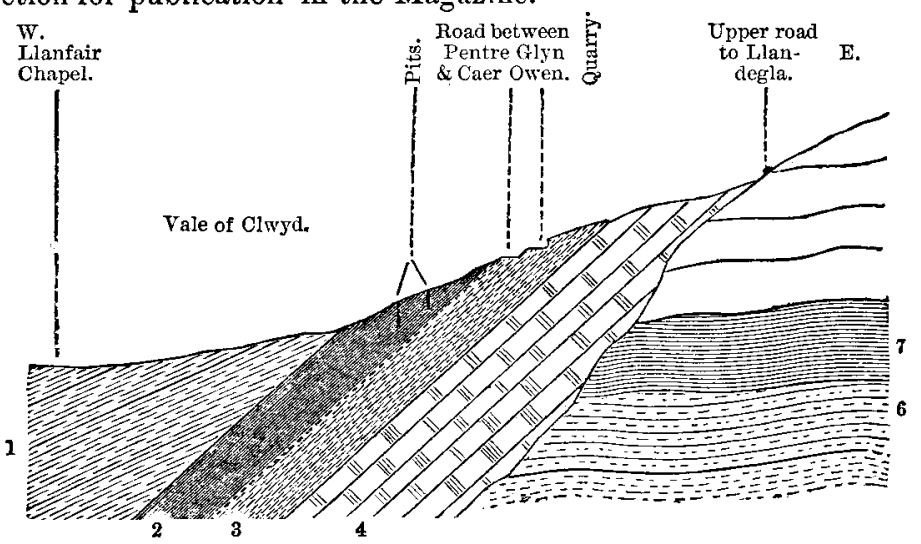

\begin{tabular}{l|l|l} 
1. Bunter Sandstone, dip $20^{\circ}$ to & 3. Purple Shales, Sandstones, \\
$30^{\circ} \mathrm{N} . \mathrm{W}$. & Slates and Grits. \\
\&c. Dip. $42^{\circ}$ S.W. & 6. Denbighshire Flags
\end{tabular}

2. Permian Miarls.

\begin{tabular}{l|l} 
\&c. Dip. $42^{\circ} \mathrm{S} . \mathrm{W}$. & 6. Denbighshire Fla \\
4. Carboniferous Limestone. & 7. Upper SiJurian. \\
Dip about $41^{\circ} \mathrm{S} . \mathrm{W}$. &
\end{tabular}

SkETCH-SECTIONS TOT DRAWN TO ScAle.

On the Geological Survey Map, sheet 74, the Mountain-limestone near Llanfair Chapel. forming the eastern boundary of the vale, is represented about a third of a mile in width. It is, however, between Pentre Celyn and Caer Owen, much narrower; the whole of the space to the west of the road, and part of that to the east, consisting of an alternation of red marls, variegated shaly beds and purplish sandstones, and pebble beds, with some impure concretionary lime- 